\title{
Requests for late termination of pregnancy: Tower Hamlets, 1983
}

\author{
WENDY SAVAGE
}

\begin{abstract}
The case histories of all women seeking late (more than 20 weeks' gestation) abortion in the NHS district of Tower Hamlets in 1983 were assessed. Of 12 women requesting late abortion, seven underwent termination of pregnancy. All the women had severe social or psychological problems, or both. The main reasons for late presentation were denial of pregnancy, youth, and mental disorder.
\end{abstract}

In a small group of atypical women late abortion seems to be justified for reasons other than fetal abnormality

\section{Introduction}

Improvements in the management of very low birthweight infants have increased their chances of survival and led many gynaecologists to question the ethics and legality of terminating pregnancies after 24 weeks' gestation. ${ }^{1}$ Much of the debate about this issue is based on an assumption that late abortion (defined as termination of pregnancy after 20 weeks' gestation) is justifiable only on the grounds of a substantial risk of severe fetal abnormality. The study of late abortion by the Royal College of Obstetricians and Gynaecologists documented the importance of delay due to the system in a substantial number of women obtaining abortions after 20 weeks, ${ }^{2}$ but in practice most such late operations are done in women who present late but are nevertheless thought to have grounds for termination based on their medical history or social circumstances. Here I describe the late terminations that were carried out in one National Health Service district in one year and also the requests for late operations that were not carried out.
\end{abstract}

\section{Case reports}

Of 894 women seen at the day care abortion service in Tower Hamlets in 1983,790 had their pregnancies terminated. Nine women were more than 20 weeks pregnant at presentation, and another two women came to the antenatal clinic and requested termination. One further woman admitted for tonsillectomy was found to be 24 weeks pregnant and was referred. No woman who presented before 20 weeks' gestation was operated on after 20 weeks. Thus 12 requests $(1.5 \%)$ were late. (No terminations after 20 weeks' gestation for fetal abnormality or other reasons were performed by the other consultants in Tower Hamlets in 1983.) Of the 12 women presenting late, seven $(0.9 \%)$ had their pregnancies terminated after 20 weeks.
Table I gives details of the 12 patients presenting late, two of whom are described in detail below.

Case 6-A 12 year old girl was referred by her general practitioner at 21 weeks after her last menstrual period, which had been light, after her gym mistress had noted her swelling abdomen. On examination the uterus was compatible with 26 weeks' gestation, and her mother confirmed that she had had a normal menstrual period four weeks earlier than her last bleed, at Christmas. Ultrasound scanning gave a biparietal diameter that was the mean for 26.5 weeks' gestation, with a range of 1.5 weeks. The girl said that she had not felt fetal movements but that soon after school had restarted in January she had been raped in the lift in the block of flats where she lived by a man smelling of alcohol. Her mother had also denied the pregnancy, saying that she thought the weight gain was "puppyfat" and that as her daughter never went out she had not thought that pregnancy was a possibility; she was preoccupied with looking after her 14 year old twins as well as the patient and working as her husband was in prison. Although a well built girl, the patient was a young 12 year old, and, after confirming with the general practitioner that he was prepared to continue to be a signatory to the green form even though the pregnancy was farther advanced than he had thought, I agreed to terminate the pregnancy on the grounds of her immaturity and mental health. An epidural was used, and she aborted within 10 hours. The fetus and placenta weighed $1100 \mathrm{~g}$, and the foot length was $5.0 \mathrm{~cm}$, the mean for 26 weeks and the upper limit for 25 weeks. There were no adverse physical sequelae, and follow up by a child psychiatrist is still continuing over a year later. There are multiple social problems, and it recently emerged that the man alleged to have raped her is sexually involved with her mother, who is now working as a prostitute.

Case 10-A 37 year old woman, who was married for the third time, had a long history of psychiatric disorder combined with drug and alcohol abuse. Two weeks before she was referred by her general practitioner in south London she had failed to keep an appointment that she had made for herself at the day care abortion service, having left her husband and six children by their various marriages. She thought that her last menstrual period had been three months earlier, but on examination the uterus was compatible with 24 weeks' gestation and she was found to be suffering from agitated depression. When the duration of the pregnancy had been confirmed by ultrasound scanning she decided against a termination (she had had one abortion at 10 weeks just before her marriage, having conceived by a casual partner before she had had intercourse with her fiancé), although I thought that she had grounds for this on the basis of her mental health and the physical and mental health of her existing children. Her husband also said that he could not cope with any more children and his wife in her present mental state. He had had a problem with alcohol in the past, several general practitioners had removed the family from their lists so that they were not registered with one, and the patient had fallen out with her health visitor after the health visitor had given evidence in a court case after a fire at the house. She had a difficult pregnancy and required much psychiatric support. At term she had a normal delivery of a boy weighing $3300 \mathrm{~g}$, who died in a fire at their house some months after birth.

\section{Technique of abortion}

The method of abortion chosen was unlikely to result in the delivery of a living fetus. As much liquor as possible was removed followed by intraamniotic instillation of prostaglandin $E_{2} 5 \mathrm{mg}$ and urea $40 \mathrm{~g}$. Six of the seven women aborted within eight to 12 hours; one of these required manual removal of placenta under general anaesthesia. The seventh required extraamniotic prostaglandin and took 62 hours to abort. Six cases were uncomplicated, and one girl was readmitted with pelvic infection 10 days later, which responded rapidly to erythromycin and metronidazole (Flagyl).
Departent London E1 and honorary consultant, London Hospital 
TABLE I-Details of women requesting termination of pregnancy after 20 weeks, Tower Hamlets 1983

\begin{tabular}{|c|c|c|c|c|c|c|c|c|c|c|c|}
\hline $\begin{array}{l}\text { Case } \\
\text { No }\end{array}$ & $\underset{(\text { years })}{\text { Age }}$ & $\begin{array}{c}\text { Marital } \\
\text { state }\end{array}$ & Parity & $\begin{array}{l}\text { Ethnic } \\
\text { group }\end{array}$ & $\begin{array}{l}\text { Referred } \\
\text { to DCAS } \\
\text { by GP }\end{array}$ & $\begin{array}{l}\text { Dates } \\
\text { agree } \\
\text { with } \\
\text { size? }\end{array}$ & $\begin{array}{c}\text { Fundal } \\
\text { height } \\
\text { measured at } \\
\text { DCAS }\end{array}$ & $\begin{array}{l}\text { Best estimate of } \\
\text { gestation* } \\
\text { (weeks) }\end{array}$ & $\begin{array}{l}\text { Outcome } \\
\text { of request }\end{array}$ & $\begin{array}{l}\text { Factors in } \\
\text { late presentation }\end{array}$ & Follow up \\
\hline 1 & 13 & Single & 0 & English & $\begin{array}{l}\text { Yes, but to } \\
\text { ANC first }\end{array}$ & No & $22-24$ & $\begin{array}{l}24-26 \\
(\mathrm{FL} 5 \cdot 1 ; \mathrm{CRL} 20 ; 720 \mathrm{~g})\end{array}$ & TOP & $\begin{array}{l}\text { Youth, fear, } \\
\text { denial }\end{array}$ & $\begin{array}{l}\text { Referred from outpatients } \\
\text { department to YPC at } 6 \\
\text { weeks. GP prescribed }\end{array}$ \\
\hline 2 & 19 & Single & 0 & English & No (none) & No & 22 & \multirow{3}{*}{$\begin{array}{l}24 \\
\left(\mathrm{FL} 4 \cdot 9 ; \text { CRL }_{20} 0 ; 575 \mathrm{~g}\right) \\
25 \\
(\text { FL } 4 \cdot 8 ; \text { CRL } 18 ; 700 \mathrm{~g}) \\
>22 \\
(\mathrm{FL} 4 \cdot 2 ; \text { CRL } 16 ; 400 \mathrm{~g})\end{array}$} & TOP & Denial & $\begin{array}{l}\text { Referred to YPC. } \\
\text { Did not attend }\end{array}$ \\
\hline 3 & 15 & Single & 0 & English & No & No & $24-26$ & & TOP & Youth, denial, & One year seeing child \\
\hline 4 & 17 & Single & 0 & West Indian & Yes & No & $22-24$ & & TOP & $\begin{array}{l}\text { menstruation } \\
\text { Youth, denial }\end{array}$ & $\begin{array}{l}\text { psychiatrist } \\
\text { Finished college course; } \\
\text { pregnant again; } \\
\text { delivered } 3000 \mathrm{~g} \text { baby } \\
16 \text { months after } \\
\text { termination }\end{array}$ \\
\hline 5 & 15 & Single & 0 & English & $\mathrm{No}$ (to ANC) & Yes & 21 & \multirow{3}{*}{$\begin{array}{l}21 \\
\text { (FL } 3 \cdot 6 \text {; fetus and placenta } 650 \mathrm{~g} \text { ) } \\
25-26 \\
\text { (Kidney and lung microscopy; } \\
\text { FL } 5 \cdot 7 ; \text { fetus and placenta } 1100 \mathrm{~g} \text { ) } \\
25 \\
\text { (BPD } 6.5 \mathrm{~cm} ; \mathrm{FL} 4 \cdot 5 ; 950 \mathrm{~g} \text { ) }\end{array}$} & TOP & Youth, denial & One year seeing child \\
\hline 6 & 12 & Single & 0 & $\begin{array}{l}\text { Father West } \\
\text { Indian; mother } \\
\text { English }\end{array}$ & Yes & No & 26 & & TOP & $\begin{array}{l}\text { Rape, youth, } \\
\text { denial }\end{array}$ & $\begin{array}{l}\text { Continuing with child } \\
\text { psychiatrist }\end{array}$ \\
\hline 7 & 16 & Single & $\begin{array}{l}\text { One spontaneous } \\
\text { abortion at } 12 \\
\text { weeks }\end{array}$ & $\begin{array}{l}\text { English } \\
\text { En }\end{array}$ & $\begin{array}{l}\text { Yes (at second } \\
\text { visit) }\end{array}$ & No & $22-24$ & & TOP & Denial & $\begin{array}{l}\text { Adult psychiatrist but } \\
\text { attended only once }\end{array}$ \\
\hline 8 & 39 & Divorced & $\begin{array}{l}\text { Two live births; } \\
1 \text { TOP at } 17 \text { weeks }\end{array}$ & English & $\begin{array}{l}\text { Yes (at three } \\
\text { months) }\end{array}$ & No & 22 & $\begin{array}{l}22 \text { at referral } \\
(3420 \mathrm{~g} \text { at } 41 \text { weeks })\end{array}$ & $\begin{array}{l}\text { TOP agreed } \\
\text { but patient } \\
\text { discharged } \\
\text { herself }\end{array}$ & $\begin{array}{l}\text { Mental state, } \\
\text { possibly drug } \\
\text { abuse }\end{array}$ & $\begin{array}{l}\text { Stillbirth; arrived in } \\
\text { labour ward fully } \\
\text { dilated }\end{array}$ \\
\hline 9 & 37 & $\begin{array}{c}\text { Married } \\
\text { (third time) }\end{array}$ & $\begin{array}{l}\text { Four live births; } \\
1 \text { spontaneous } \\
\text { abortion; } 1 \text { TOP at } \\
10 \text { weeks }\end{array}$ & Irish & Yes & No & $22-24$ & $\begin{array}{l}22 \text { at referral } \\
3300 \mathrm{~g} \text { at delivery })\end{array}$ & $\begin{array}{l}\text { TOP } \\
\text { recom- } \\
\text { mended; } \\
\text { decided } \\
\text { against }\end{array}$ & $\begin{array}{l}\text { Mental illness; } \\
\text { drug and alcohol } \\
\text { abuse }\end{array}$ & $\begin{array}{l}\text { Baby died in fire some } \\
\text { months later }\end{array}$ \\
\hline 10 & 22 & Single & 0 & Yoruba & $\begin{array}{l}\text { No at three } \\
\text { months } \\
\text { (ANC later) }\end{array}$ & No & 24 & $\begin{array}{l}24 \\
\text { (USS; } 3100 \mathrm{~g} \text { at delivery) }\end{array}$ & $\begin{array}{l}\text { Agreed to } \\
\text { continue }\end{array}$ & $\begin{array}{l}\text { Communication } \\
\text { with GP and his } \\
\text { attitude; }\end{array}$ & $\begin{array}{l}\text { TOP of second } \\
\text { pregnancy at } 16 \text { weeks } \\
\text { owing to pill failure }\end{array}$ \\
\hline 11 & 14 & Single & 0 & Bengali & No (to ANC) & Unknown & $30(\mathrm{ANC})$ & 29 & $\begin{array}{l}\text { Too late for } \\
\text { TOP }\end{array}$ & $\begin{array}{l}\text { Rape; in } \\
\text { Bangladesh till } \\
28 \text { weeks }\end{array}$ & $\begin{array}{l}\text { Baby fostered before } \\
\text { adoption; cot death }\end{array}$ \\
\hline 12 & 22 & Single & $\begin{array}{c}\text { One TOP at } \\
10 \text { weeks }\end{array}$ & English & Yes & Yes & 22 & $\begin{array}{l}22 \text { at referral } \\
\text { (USS one month later, with } \\
\text { BPD mean for } 26 \text { weeks) }\end{array}$ & Refused & Notes inadequate & $\begin{array}{l}\text { Assisted breech at term; } \\
\text { still taking pill } \\
1 \text { year later }\end{array}$ \\
\hline
\end{tabular}

^ Based on biparietal diameter (BPD), measured by ultrasound scanning (USS), foot length (FL), crown to rump length (CRL), and weight.
DCAS = Day care abortion service; $A N C=$ antenatal clinic; TOP $=$ termination of pregnancy; YPC = young people's clinic.

\section{Discussion}

In England and Wales for the years 1982 and 1983 respectively, 975 and 1085 abortions $(0.8 \%$ of those performed on resident women) were performed at 21 weeks or more. ${ }^{34}$ The incidence in Tower Hamlets was identical. In England and Wales, of terminations done at between 21 and 24 weeks, three times as many were done in non-NHS premises as were paid for by the NHS; at 25 weeks and above, however, the position was reversed. As table II shows, in 1982 just over half of the 78 abortions done at 25 or more weeks' gestation were paid for by the NHS, and in 1983, 50 of the 87 cases were NHS funded. The proportion done at 25 weeks or more remained remarkably constant at $0.06 \%$ of the total for several years.

These numbers are small as a proportion of all terminations of pregnancy, but very late abortions have an immense emotional effect on the doctors and nurses dealing with these distressed women. Ketting has, however, pointed out that the later a woman applies for an abortion the more she needs it. ${ }^{5}$ Our experience in Tower Hamlets showed that youth and mental disorder were major factors in the denial of pregnancy, which is the psychological defence mechanism used unconsciously by these women to protect themselves. In this series the major reason for late termination was the youth of the women, often combined with family problems such as separation or divorce. This was similar to experience in previous years, although in 1983 there were no mentally handicapped women. In previous years one or two women presenting late had

TABLE II-Numbers of abortions performed at 25 or more weeks' gestation in 1982 and 1983 according to funding and type of premises where operation was done

\begin{tabular}{|c|c|c|c|c|}
\hline \multirow{2}{*}{ Year } & \multicolumn{2}{|c|}{ NHS funded } & \multirow{2}{*}{ Non-NHS } & \multirow{2}{*}{ Total } \\
\hline & NHS & Agency for NHS & & \\
\hline $\begin{array}{l}1982 \\
1983\end{array}$ & $\begin{array}{l}37 \\
44\end{array}$ & $\begin{array}{l}5 \\
6\end{array}$ & $\begin{array}{l}36 \\
37\end{array}$ & $\begin{array}{l}78 \\
87\end{array}$ \\
\hline
\end{tabular}

fallen into this category, and another factor, incest, has been even less common, with one case every two years. In two of the seven pregnancies that were terminated the patient was one of six children being cared for by an unsupported mother; none of the patients had both natural parents living in harmony. One girl continued to menstruate until admitted for a surgical operation at 24 weeks' gestation.

In the past seven years I have seen only one woman (apart from case 14) who requested termination of her pregnancy after 28 weeks, and she like the young Bengali girl in the present series was admitted to the antenatal ward until her social problems had to some extent been sorted out. It seems that once fetal movements are strong or the uterus nears the umbilicus only the youngest women or those severely mentally ill or handicapped will be able to continue using denial as a protective mechanism, and even the most unobservant of mothers can no longer ignore the swelling abdomen of their daughters. In the recent study of late abortion by the Royal College of Obstetricians and Gynaecologists $20 \%$ of the abortions done at over 20 weeks were in women who had presented before 12 weeks, ${ }^{2}$ and one patient here (case 9) is an example of this kind of delay; after discussion (with me) she agreed to continue her pregnancy. Of the five women who continued with their pregnancies, one who moved out of the district is married and caring for her baby adequately, one is struggling to rear her baby and complete her education and had a termination at 18 weeks of another unplanned pregnancy in April 1984. Little information is available about the three other women, but none of their babies is alive. One woman had a stillbirth at term having been admitted fully dilated; no fetal heart beat was audible on auscultation. The Bengali baby died at two months as a cot death while with foster parents before planned adoption. The death of the remaining infant in a fire is described above.

Of the seven teenagers whose pregnancies were terminated, one left the district immediately and did not attend for contraceptive follow up and three attended the child psychiatrist and had no further pregnancies in one year of follow up. One, aged 17, finished her course at college and then had a planned pregnancy delivered at term 16 months after the termination. Two are known by their 
general practitioners not to have become pregnant again within the year of follow up, although one attended for contraceptive advice.

Kaltreider $e t$ al reported on the feelings of doctors and nurses towards second trimester abortions done in theatre by dilatation and evacuation or in the ward using intra-amniotic methods and found that doctors and theatre nurses preferred the second method and ward nurses the first. ${ }^{6}$ In Tower Hamlets not all the ward staff or duty medical team felt able to take part in these late abortions, and this adds to the stress of those who do participate and may also be a factor in the consistently low proportion of very late abortions done in England and Wales.

Women requesting late abortions are, then, an atypical group with many social and psychological problems. A change in the law restricting legal abortion to 24 weeks' gestation or less would have prevented 78 abortions in 1982 and 87 in 1983, about a fifth of which were for fetal abnormality, ${ }^{7}$ and in Tower Hamlets would have prevented at least three deprived teenagers from ending their pregnancies and starting afresh. The close cooperation of a child psychiatrist has helped these vulnerable teenagers to cope.

My policy has been to assess each case on its merits and to try to minimise the psychological trauma to the mothers. I recognise that, regrettably, in some cases this has meant termination of pregnancy when the fetus was nearing natural viability.

I do not believe that the answer lies in a change in the law. Abortions at over 20 weeks are often associated with delay in the system as documented by many workers in this country ${ }^{8-10}$ and could be reduced in number by the provision of NHS day care facilities. Since the day care abortion service opened in July 1977 the proportion of abortions done at 17 weeks or more has fallen from $9 \%$ in 1975 to $1.8 \%$ in 1982 . In the small numbers of very late cases parents, teachers, and doctors are often in contact with the women concerned, and awareness of the possibility of pregnancy might enable an earlier diagnosis to be made.

I thank the Spencer Ward nurses, led by Sister Heyes, without whose humanity and unstinting support this work would not have been possible; my psychiatric colleagues Dr Alyson Hall and Dr Gillian Waldron for advice and after care; and Professor Colin Berry for providing pathology back up.

\section{References}

1 Paintin D. Late abortion 1984: problems and possibilities. In: Abortion services in London. London: Women's Reproductive Rights London Survey, 1984. (Report of a conference in 1984. Funded by the GLC Women's Committee.)

2 Alberman E, Dennis KJ, eds. Royal College of Obstetricians and Gynaecologists late abortion survey. London: Royal College of Obstetricians and Gynaecologists, 1984: table 2.10.

3 Office of Population Censuses and Surveys. Abortion monitor AB83/5. London: OPCS, 1983.

4 Office of Population Censuses and Surveys. Abortion monitor AB84/6. London: OPCS, 1984. petting E. Second trimester abortion as a social problem. In: Kierse
pregnancy termination. The Hague: Leiden University Press, 1982:16.

6 Kaltreider NB, Goldsmith S, Margolis AJ. The impact of midtrimester abortion techniques on patients and staff. Obstet Gynecol 1979;135:235-8.

7 Alberman E, Kani W, Stanwell-Smith R. Congenital abnormalities in legal abortions at 20 week or later. Lancet 1984; ;: 1226-7.

8 Ashton JR. Components of delay amongst women obtaining termination of pregnancy. $\mathcal{J}$ Bioso Sci $1980 ; 12: 261-5$.

9 Allen I. Family planning and sterilization services. London: Policy Studies Institute, 1981.

10 Brewer $\mathrm{C}$. Induced abortion after feeling fetal movements. Its causes and emotional consequences. f Biosoc Sci 1978;10:203-8.

(Accepted 16 November 1984)

\title{
Measles matters, but do parents know?
}

\author{
S BLAIR, N SHAVE, J MCKAY
}

\begin{abstract}
Two hundred and one parents attending three child health clinics were questioned about both measles and immunisation against measles. Most parents were unaware of the symptoms and possible complications of measles and did not believe immunisation to be effective in preventing measles. They did not remember having talked to health professionals about immunisation.
\end{abstract}

\section{Introduction}

Britain has failed to immunise its population effectively against measles. ${ }^{1}$ Members of the Riverside Child Health Project were concerned about this and asked parents who were attending child health clinics for their views on measles and on immunisation against measles to see why many parents did not have their children immunised against measles.

\footnotetext{
Riverside Child Health Project, Atkinson Road Infant School, Newcastle upo Tyne

S BLAIR, MRCP, fellow and senior registrar in community paediatrics

University of Newcastle upon Tyne, Tyne and Wear

N SHAVE, medical student

J MCKAY, medical student

Correspondence to: Dr S Blair, Community Child Health Services, North Tyneside Health Authority, North Shields NE29 0HG.
}

The Riverside Child Health Project is based in an inner city area of Newcastle upon Tyne. The project team is responsible for developing community child health services in the area. Forty five per cent of children born in 1982 who attended the three child health clinics at Riverside were immunised against measles. ${ }^{2}$ The clinical experiences of the project's doctors in hospitals and the community had brought to their attention the suffering caused by measles and its more serious complications, particularly pneumonia and encephalitis.

\section{Subjects and methods}

A questionnaire was produced by the project team and used to ask parents their views about measles and its complications. They were also asked their views on the effectiveness of immunisation against measles and about any harmful effects or side effects and whether they had observed measles in their family or elsewhere. The parents' recollections of conversations with health professionals about measles were recorded. At the end of the interview parents were shown a flash card with a picture and description of three infectious diseases-namely, measles, chicken pox, and rubella. They were asked to identify which one they thought was measles.

The interviews were carried out by two medical students (JM, NS) over two and a half months. After each interview any issues raised by the interviewee were discussed with one of the two interviewers with reference to an information leaflet that the parents had received. ${ }^{3}$ The aim of this discussion was to improve parents' understanding of measles and measles immunisation and to overcome any misconceptions brought up in the interviews.

Two hundred and one parents, one for each child attending the clinics, were interviewed. Equal numbers of parents were seen at each clinic, and almost all of those asked agreed to participate: only six declined. The children attending the clinic at the time of this study were aged as follows: 0 3 months, 55 children; 4-6 months, 43; 7-11 months, 42 ; over 11 months, 61 . 